\title{
REBOUND FROM THE PERMIAN/TRIASSIC MASS EXTINCTION: EVOLUTIONARY PALEOECOLOGY OF SEQUENTIAL EARLY TRIASSIC (SMITHIAN TO SPATHIAN) MARRNE PALEOCOMMUNTTIES.
}

SCHUBERT*, Jennifer K., Dept. of Geological Sciences, University of Southern California, Los Angeles, CA 90089-0740, U.S.A.; BOTTJER, David J., Dept. of Geological Sciences, University of Southern California, Los Angeles, CA 90089-0740, U.S.A.

The Permian/Triassic mass extinction, the most devastating biotic crisis of the Phanerozoic, has aroused considerable scientific interest. However, because research has focused primarily on understanding the magnitude of diversity reduction and causal mechanisms, the nature and timing of biotic recovery in the Early Triassic are still poorly understood. Marine limestones in the Lower Triassic Moenkopi Formation, which disconformably overlies the Upper Permian of southeastern Nevada and southern Utah. provide a rare opportunity to study the aftermath of the mass extinction in shallow water carbonate environments.

Two contemporaneous members of the Moenkopi record the first marine incursion from the northwest in the Early Triassic (Smithian), the very sparsely fossiliferous marginal marine Schnabkaib Member in Nevada and southwest Utah, and the Sinbad Limestone in central-southern Utah, a marine unit dominated by amalgamated and condensed fossilrich beds. The Virgin Limestone member was deposited during a subsequent (Spathian) Early Triassic sea level rise, about 4.5 Ma following the Permian/Triassic boundary, and includes nearshore and inner shelf limestones characterized by fossiliferous storm beds.

Because the fossiliferous limestones of the Smithian Sinbad and the Spathian Virgin were deposited in similar shallow subtidal settings, they provide an opportunity to compare and contrast the status of biotic rebound at different points along an Early Triassic "time transect." Analysis of bulk samples reveals that the older Sinbad and younger Virgin are similar in each possessing 2.3 different benthic marine paleocommunities of low within-habitat species richness. There are, however, several important differences between the Sinbad and Virgin faunas. The richly fossiliferous Sinbad assemblages are primarily molluscan, composed of approximately 2.8 species of bivalves, which may or may not be accompanied by ammonoids and $0-11$ species of gastropods. Small spines, possibly belonging to an echinoid, are numerous in some samples. Although bivalves are also abundant in Virgin Limestone assemblages, fossils of other higher taxa are well-represented, including abundant crinoid ossicles, common brachiopods, echinoid spines and plates, and rare ammonoids and gastropods. Sinbad faunas also appear to lack epibionts and borers, while they are present but not abundant in the Virgin.

The addition from Sinbad to Virgin times of groups other than molluscs, with different life habits and strategies, most likely led 10 an increase in spatial partitioning and resource utilization, in particular the development of epifaunal tiering with the appearance of stalked crinoids in the Virgin. This pattern of carliest Triassic community dominance by molluscs followed by later more "Paleozoic-like" communities has been observed in other regions. Earliest Triassic paucity of epibionts and borers indicates significant reduction in the biotic component of taphonomic processes, including taphonomic feedback, when compared with other time intervals. Data from these Early Triassic assemblages thus indicate the initiation of both an evolutionary and an ecological rebound between Sinbad (Smithian) and Virgin (Spathian) times. 